\title{
The SPS Agreement as a bottleneck in agricultural trade between the European Union and developing countries: How to solve the conflict
}

Citation for published version (APA):

Prevost, D., \& Matthee, M. (2002). The SPS Agreement as a bottleneck in agricultural trade between the European Union and developing countries: How to solve the conflict. Legal Issues of Economic Integration, 29(1), 43-59. https://doi.org/10.2139/ssrn.1260271

Document status and date:

Published: 01/01/2002

DOI:

10.2139/ssrn.1260271

Document Version:

Publisher's PDF, also known as Version of record

\section{Please check the document version of this publication:}

- A submitted manuscript is the version of the article upon submission and before peer-review. There can be important differences between the submitted version and the official published version of record.

People interested in the research are advised to contact the author for the final version of the publication, or visit the DOI to the publisher's website.

- The final author version and the galley proof are versions of the publication after peer review.

- The final published version features the final layout of the paper including the volume, issue and page numbers.

Link to publication

\footnotetext{
General rights rights.

- You may freely distribute the URL identifying the publication in the public portal. please follow below link for the End User Agreement:

www.umlib.nl/taverne-license

Take down policy

If you believe that this document breaches copyright please contact us at:

repository@maastrichtuniversity.nl

providing details and we will investigate your claim.
}

Copyright and moral rights for the publications made accessible in the public portal are retained by the authors and/or other copyright owners and it is a condition of accessing publications that users recognise and abide by the legal requirements associated with these

- Users may download and print one copy of any publication from the public portal for the purpose of private study or research.

- You may not further distribute the material or use it for any profit-making activity or commercial gain

If the publication is distributed under the terms of Article $25 \mathrm{fa}$ of the Dutch Copyright Act, indicated by the "Taverne" license above, 


\title{
The SPS Agreement as a Bottleneck in Agricultural Trade between the European Union and Developing Countries: How to Solve the Conflict
}

\author{
Denise Prévost and Mariëlle Matthee*
}

\section{Introduction}

It is crucial that developing country concerns regarding the Agreement on the Application of Sanitary and Phytosanitary Measures (hereinafter the SPS Agreement) urgently be addressed in the WTO in order to ensure that these countries experience the full benefits of trade. There has been much talk that the new negotiating round in the WTO, which was launched in Doha, will be a Development Round. ${ }^{1}$ To ensure the success of the new round, reforms are necessary in sectors of importance for developing countries in order for these Members to perceive the advances in trade liberalisation as, on balance, advantageous to them. On the other hand, for reforms to be agreed upon they have to take account of the interests of developed country Members, such as the European Community, which are often in conflict with those of developing countries, particularly in sensitive sectors.

The agricultural sector is pivotal in this regard as many developing countries' economies rely on agricultural trade as a primary source of foreign revenue. However, this sector is subject to a great deal of protectionist measures in the EC and elsewhere. Clearly, progress towards removal of these traditional trade barriers (such as subsidies and tariffs) can be undermined by the use of health regulations to block entry of imports. Thus, in order to ensure real market access for agricultural products, the ongoing reform process for agricultural liberalisation in the WTO, as mandated by Article 20 of the Agreement on Agriculture (hereinafter the AoA), must go hand in hand with reforms to the SPS Agreement. This fact is not only evinced by the close

* Denise Prévost is a researcher and PhD candidate at the Department of International and European Law, University of Maastricht. Mariëlle Matthee is research fellow at the T.M.C. Asser Institute in The Hague and PhD candidate at the University Paris I: Panthéon-Sorbonne.

1. This new terminology was stated to be intended to signal a different set of priorities in the negotiations. The Doha Ministerial Declaration specifically states that Members seek to place the needs of developing countries at the heart of the Work Programme adopted therein (see Ministerial Declaration, Ministerial Conference, Fourth Session, hereinafter the Ministerial Declaration, WT/MIN(01)/DEC/W/1 at para. 2). 
link between these two agreements during their original negotiation in the Uruguay Round, but also by the fact that most negotiating proposals in the context of the mandated agriculture negotiations contain some reference to SPS concerns. A recent study by the $\mathrm{FAO}^{2}$ points to the fact that trade in agricultural products is still hampered by non-tariff barriers, including health regulations. Thus, despite the existence of disciplines contained in the SPS Agreement, countries continue to block access to their agricultural markets by means of SPS measures. ${ }^{3}$ This has particularly harsh consequences for developing countries, many of which rely on a small number of agricultural exports. They view SPS measures as often creating unjustified non-tariff barriers to their agricultural and food exports.

The EC constitutes the main export market for developing country agricultural products and liberalisation of its agricultural industry is therefore crucial for developing countries. Influenced by a series of events directly or indirectly related to the protection of public health, such as the outbreak of mad cow disease, the Belgian dioxin scandal and the French blood-transfer case, European consumers lost trust in the governors of the European Communities. Therefore re-establishing consumer confidence is one of its major concerns at this moment. Consequently, its trade policy is greatly influenced by public opinion and the 'non-trade concerns' under the mandated negotiations on the AoA are high on the agenda. ${ }^{4}$

While it is clear that most Members see a need to review certain aspects of the SPS Agreement it is not yet established in what context such review would occur. If the SPS Agreement itself is not reopened for negotiation in the context of the new round, ${ }^{5}$ it is possible that these concerns will continue to be addressed in the context of the ongoing agriculture negotiations, as has been the case to date. ${ }^{6}$ The reference in Article 14 of the AoA to the SPS Agreement opens the door for this possibility, as does the identification of market access (thus including non-tariff barriers such as SPS measures)

2. FAO, 1999, Symposium on Agriculture, Trade and Food Security: Issues and Options in the Forthcoming WTO Negotiations from the Perspective of Developing Countries, 23-24 September 1999, FAO: Geneva at 3.

3. In a communication during the Seattle preparatory process, India noted that 'as standards are emerging as one of the major non-tariff barriers to the market access of developing countries, it is imperative that they be speedily rationalised ...' (see WT/GC/W/108 at para. 19).

4. These non-trade concerns focus mainly on food safety issues such as GMO labelling, the application of the precautionary principle and consumer concerns and animal welfare. See G/AG/NG/W/90.

5. It should be noted that no Member has formally asked that the SPS Agreement be reopened for negotiation during the new round. In fact the US has indicated that it will not support such reopening (see $\mathrm{G} / \mathrm{AG} / \mathrm{NG} / \mathrm{W} / 15$ at 2 ). However, the possibility that this may change at a later stage in the negotiations cannot be excluded.

6. For example, see G/AG/NG/W/136 at 4; G/AG/NG/W/97 and Corr. 1 at 2 and G/AG/NG/W/94 at 2. 
as one of the 'three pillars' of the ongoing agriculture negotiations and the already mentioned explicit reference in Article 20 to 'non-trade concerns' as one of the elements to be taken into account in the mandated negotiations. Developed Members, such as the European Communities, have little to gain from increased disciplines on their ability to enact SPS measures unless they can use such concessions to exact trade benefits in other sectors of interest in the context of a comprehensive round. On the other hand, concerns have been expressed that these trade-offs would allow powerful Members, on whose agricultural product markets developing countries depend, to exact a price for the tightening of SPS disciplines from developing countries in unrelated sectors. ${ }^{8}$ Another possibility is to make use of the mechanism that exists in Article 12.7 SPS of the SPS Agreement, which allows for review of the operation and implementation of the Agreement to take place in the SPS Committee, which can then make proposals for amendments to the Council for Trade in Goods. ${ }^{9}$ Certain aspects of the SPS Agreement have already been addressed in the Implementation Decision adopted in the Doha Ministerial, which was seen as a down-payment for developing countries at the start of the new Round. ${ }^{10}$

To establish what are the conflicting concerns with regard to the SPS Agreement, one must thus turn to the proposals made in the context of the agriculture negotiations. In addition, a few proposals made in the context of the Seattle preparatory process and the implementation discussions in the General Council are relevant here. This paper will not attempt to provide a comprehensive discussion of all problems raised by developing countries and the EC regarding the SPS Agreement, but focus on a few central concerns.

7. The other two pillars are export competition and domestic support.

8. UNCTAD, Trade and Development Board, 1999, TD/B/COM.1/EM.8/2 at para. 29.

9. The first review of the SPS Agreement under Article 12.7 (1998-1999) did not result in any recommendations for amendment of the text and it was agreed in the SPS Committee that any Member could propose amendments at any time for consideration in the Committee. (While concerns regarding the implementation and operation of the Agreement have been raised in SPS Committee meetings, there have been no specific proposals for amendments. On the other hand, the SPS Committee has adopted a decision on equivalence under its powers in terms of Article 12.1 SPS to facilitate the implementation of Article 4 SPS (see WTO SPS Committee 2001 Decision on Equivalence, G/SPS/19).)

10. See WTO Ministerial Conference, Fourth Session, 2001, Decision on Implementation-Related Issues and Concerns, WT/MIN(01)/W/10 (hereinafter the Implementation Decision) at para. 3. The question of the status of this decision is interesting as it cannot be regarded as an authoritative interpretation of the relevant articles of the SPS Agreement as the procedure in Article IX.2 WTO was not followed. Panels and the Appellate Body are likely to take it into account in interpreting the relevant articles of the SPS Agreement as a "subsequent agreement" under Article 31.3(a) of the Vienna Convention but in doing so they may not add to the obligations contained in the SPS Agreement. 


\section{Differing focus: market access vs. non-trade concerns}

In the first phase of the mandated agriculture negotiations, many formal negotiation proposals contained references to SPS concerns. ${ }^{11}$ Those of developing countries mainly addressed SPS issues in the context of their market access concerns, although there were a few proposals which also looked at the impact of the Agreement on non-trade concerns, such as food safety and consumer concerns. ${ }^{12}$ From an examination of these proposals it thus appears that the primary focus of developing countries with regard to the SPS Agreement is on the extent to which it can assist them in obtaining real market access for their agricultural and food exports. Issues of food safety take secondary place and are most prominent in those developing countries that are net importers of agricultural products. ${ }^{13}$ On the other hand, the primary focus in the EC proposals is on non-trade concerns, such as food quality and animal welfare. ${ }^{14}$

The reason for the developing country focus on market access is obvious. As was the case during the Uruguay Round negotiations, in the current negotiations Members realise that the hard-won progress made towards liberalisation of the agricultural sector by increasing disciplines in the areas of export competition, market access and domestic support is meaningless without disciplines to prevent Members replacing their traditional protectionist measures with non-tariff barriers such as the imposition of standards or regulations for the protection of human, plant or animal life or health. The disciplines of the SPS Agreement aim to address this problem.

The proposals indicate that there are two main areas of concern that developing countries have with regard to the effectiveness of the SPS Agreement in preventing SPS measures from becoming unjustified barriers to trade (and thus in guaranteeing market access). The first area of concern relates to the flexibility inherent in the SPS disciplines themselves, particularly with regard to the possibility of taking precautionary measures under Article 5.7 SPS and of deviating from internationally harmonised standards

11. A summary of the proposals in the second phase of the agriculture negotiations can be found in a Secretariat briefing document which refers to only two proposals relating to SPS issues, those of Japan and the ECs (see WTO Information and Media Relations Division, 2001, WTO agriculture negotiations: The issues, and where we are now at 26-27).

12. See for example the proposal of Korea in G/AG/NG/W/98 at 5.

13. The proposal from Mauritius indicates that Small Island Developing States (SIDs) are mostly food deficit countries and suggests that SIDs' inability to carry out detailed risk assessments (as required by the SPS Agreement) should not prevent them from denying entry of certain products into their territories (see G/AG/NG/W/96 at 5).

14. See G/AG/NG/W/90. 
as provided for in Article 3.3 SPS. ${ }^{15}$ This first category of concerns stands in contrast with the non-trade concerns of the EC, which would require flexibility in the existing SPS provisions. Secondly, developing countries widely express the concern that the lack of implementation by developed Members of provisions in the SPS Agreement enacted to take account of the special constraints faced by developing countries means that they continue to be confronted with insurmountable hurdles in the form of stringent SPS standards on their export markets, without being given assistance to comply with them. Although until recently the EC granted technical assistance related to SPS capacity building to several developing countries on a rather ad hoc basis, it is about to launch important technical assistance to all ACP (African, Caribbean and Pacific) countries to comply with the EU sanitary and phytosanitary rules. ${ }^{16}$ This might indicate a turning point in the EC policy on special and differential treatment of developing countries.

These two areas of concern will now be discussed in more detail and explained in the context of the existing SPS Agreement.

\subsection{Flexibility inherent in SPS disciplines}

The disciplines contained in the SPS Agreement aim at achieving a balance between the sovereign right of Members to impose measures for the protection of health in their territories and the need to liberalise trade in agriculture and food products. For this reason, they allow some flexibility for national governments in their regulation of health in their countries. It is the degree of this flexibility that gives developing countries cause for concern. They see this flexibility as eroding the strength of the disciplines and creating the possibility of abuse for protectionist purposes. On the other hand, the EC expresses its need for such flexibility in order to satisfy its consumer's concerns.

One of the disciplines contained in the SPS Agreement is the obligation

15. Additionally, the flexibility in the provisions on equivalence (Article 4 SPS) and the recognition of disease-free areas (Article 6 SPS) was raised as a problem. Although these provisions are mandatory, the lack of clear guidelines for implementation made these obligations difficult to enforce and little had been done by way of implementing these provisions. Developing countries accused developed Members of refusing to recognise disease-free areas even when officially recognised as such by the relevant international organisations and of requiring 'sameness' instead of equivalence (see G/SPS/GEN/128 at 1). On 24 October 2001, the SPS Committee (using its competence under Article 12.1 SPS) approved a decision on equivalence, aimed at facilitating the use of Article 4 SPS (see WTO SPS Committee 2001 Decision on Equivalence, G/SPS/19). The status of this decision is worth examining. Like the Implementation Decision, it does not comply with the requirements for an authoritative interpretation or an amendment of the SPS Agreement (Articles IX.2 and X WTO). Due to constraints of space, this issue will not be discussed further here, but its importance should not be underestimated.

16. See G/SPS/GEN/244, pp. 4 and 5, Indicative list of projects. 
to base SPS measures on internationally harmonised standards ${ }^{17}$ unless the stricter measures can be scientifically justified by means of a risk assessment. ${ }^{18}$ The promotion of harmonised standards by the SPS Agreement has the potential of going a long way towards reducing the non-tariff barriers faced by developing country products by ensuring that the SPS measures imposed reflect internationally accepted standards (rather than arbitrary and unreasonably stringent standards) and that products face the same requirements on all export markets.

The loopholes created in the harmonisation provision by the possibility for (scientifically justified) deviating measures are seen by developing countries as undermining these potential benefits. Developing countries do not have the technical capacity and expertise to challenge SPS measures that deviate from international standards on grounds of lack of scientific justification. Further, since scientists often disagree on issues of risk and a risk assessment does not have to embody a majority view, ${ }^{19}$ much scope is left for Members to impose more stringent SPS measures than those embodied in international standards. This diminishes the harmonising effect of Article 3 SPS and thus the benefits thereof for increasing market access for agricultural and food products.

This room to manoeuvre is, however, necessary in the view of the EC. If all countries are obliged to stick to international standards, there is fear that a downward movement of standards will result. Often the EC already has high standards in place at the time international standards are negotiated. Thus the obligation to accept international standards would most probably paralyse the standard-setting process, as the EC would in that case have every interest in obstructing the development of a new international standard, which contains a lower level of protection than its own. As regards the minority opinion of scientists, this is seen by the EC as one of the main ways to ensure the application of the precautionary principle during the risk assessment procedure. In their opinion, the inclusion of minority views in the risk assessment reports must be assured, especially in the case that the minority opinion draws attention to scientific uncertainty. ${ }^{20}$

The SPS Agreement further disciplines Members' use of SPS measures by requiring that such measures be based on scientific principles (in the form of a risk assessment). ${ }^{21}$ This obligation ensures that SPS measures address a real, objectively established, health risk and are not protectionist measures

17. Article 3.1 SPS.

18. Article 3.3 SPS as interpreted by the Appellate Body in EC-Hormones (see WT/DS26/B/R at para. 175).

19. See the Appellate Body report in EC-Hormones (WT/DS26/B/R at para. 175). This finding has been criticised for opening the door for the use of 'hired scientists' by governments to justify their measures (see D.E. McNiel, 1998 Virginia J of Int'l L 39: 89-134 at 134.)

20. See G/SPS/GEN/225, G/TBT/W/154, G/CTE/W/181, at 3.

21. Article 2.2 SPS read together with Article 5.1 SPS. 
disguised as health regulations. However, an exception to this obligation is provided for in Article 5.7. Article 5.7 allows for provisional SPS measures, based on available pertinent information, in cases where scientific evidence is insufficient, provided that a Member seeks to obtain additional information for a more objective risk assessment and reviews the measure within a reasonable period of time.

The allowance made in Article 5.7 for precautionary measures gives developing countries cause for concern. The terms used in Article 5.7 are rather vague and undefined. It is not clear what would constitute 'pertinent information' sufficient to justify a provisional measure, how long such a measure may be maintained while keeping its character as 'provisional' or what the obligation to 'seek to obtain . . . additional information' entails. ${ }^{22}$ This creates the possibility that insufficiently justified measures could be maintained for long periods of time.

In order to respond to European consumer concerns and to regain their confidence, the EC pays special attention to the use of the precautionary principle. There is public concern that the WTO can be used to force onto the market products for which there is a reasonable suspicion that they might be unsafe. Under the precautionary principle, the EC can provisionally adopt measures to protect human health, when there is a legitimate reason to believe that the product in question may contain risks but insufficient information exists to identify them. It is therefore a useful instrument for the EC to respond to public concerns. In its communication on the precautionary principle, the European Commission has indicated that in its opinion the provisional nature of a measure should not be determined by time restrictions, but rather be delineated by the development of scientific knowledge. ${ }^{23}$

Due to the flexibility inherent in the language of these provisions, developing countries have proposed that the disciplines in the SPS Agreement be tightened. In particular, some proposals have suggested that all Members should be obliged to apply internationally harmonised SPS standards that reflect the constraints faced by developing countries. A clarification of the requirements of Article 5.7 by means of concrete guidelines indicating under which conditions a provisional measure may be applied has also been suggested. Aware that the precautionary principle is to a certain extent reflected in Article 5.7, and that misuse and legal uncertainty should be avoided, there is a need for clarification on the use of the precautionary principle, the EC has developed several documents in which they explain their approach towards its use. In addition, they have repeatedly called for further clarification on this issue. ${ }^{24}$

22. The Appellate Body took some steps towards the clarification of two of the requirements of Article 5.7 in Japan - Agricultural Products, WT/DS76/AB/R, paras. 92-93.

23. See G/SPS/GEN/168.

24. See $\mathrm{G} / \mathrm{AG} / \mathrm{NG} / \mathrm{W} / 90$, at 4 . 


\subsection{Lack of consideration for developing country constraints}

The SPS Agreement provides for special and differential treatment (S\&D treatment) of developing country Members and for the provision of technical and financial assistance, in order to take into account the special constraints that these Members face due to their economic and developmental situations. ${ }^{25}$ In particular, in Article 9 SPS, Members agree to 'facilitate the provision of technical assistance to other Members, especially developing country Members' in order to allow them to adjust to and comply with SPS standards in their export markets. ${ }^{26}$ This assistance can take the form of 'advice, credits, donations or grants'. Where compliance with the SPS measure would entail 'substantial investments' by a developing country, the importing Member 'shall consider' providing the technical assistance necessary for the developing country Member to maintain or expand its market access opportunities for the relevant product. ${ }^{27}$ Article 10 SPS obliges Members to take developing country Members' special needs into account in the preparation and application of SPS measures. ${ }^{28}$ Further, it provides that Members 'should' accord longer time-frames for compliance with new SPS measures on products of interest to developing country Members, where the appropriate level of SPS protection allows, ${ }^{29}$ and that they 'should' encourage and facilitate active developing country participation in the international standard-setting bodies. ${ }^{30}$ Paragraph 2 of Annex B SPS obliges Members to allow a 'reasonable interval' between the publication of an SPS measure and its entry into force to allow producers 'particularly in developing country Members' to adapt to the new measure '(e)xcept in urgent circumstances'. The examination of these provisions shows that many of the $\mathrm{S} \& \mathrm{D}$ treatment provisions contain no binding obligations beyond a 'best endeavour' commitment, or are qualified in a way that makes evasion easy.

Developing countries argue that the flexible language of these provisions creates no enforceable obligations and thus allows developed countries to

25. There are two types of S\&D treatment provisions in the WTO Agreements, namely (1) time limited derogations (such as longer transition periods) and (2) clauses providing for specific, though undefined, action by developed countries when dealing with developing countries. As the second category is most problematic, this paper will limit itself to this type of provision (see WT/GC/W/108 at paras. 5-7).

26. Article 9.1 SPS.

27. Article 9.2 SPS.

28. Article 10.1 SPS.

29. Article 10.2 SPS.

30. Article 10.4 SPS. 
disregard them. The inadequacy of the implementation ${ }^{31}$ of these provisions is a common complaint of developing countries and has been raised in the framework of the implementation discussions in the General Council ${ }^{32}$ and in the Seattle preparatory process as well. ${ }^{33}$ There is a clear need for the operationalisation of $S \& D$ treatment and there have been many calls for the strengthening of these rules. ${ }^{34}$

While many developing country proposals in this regard merely refer, in general terms, to the need for consideration of their special situation, technical and financial assistance to meet SPS standards and assistance for their participation in international standard-setting (thus implying that the current rules do not effectively provide for these needs), ${ }^{35}$ other proposals are more specific and expressly state that Articles 9 and 10 must be made mandatory for developed country Members. ${ }^{36}$ In addition, some proposals suggest the laying down of specific time frames for the imposition of new measures ${ }^{37}$

31. That is not to say that no technical assistance relating to SPS concerns has been delivered at all. In fact several Members have submitted papers to the SPS Committee documenting the technical assistance they have provided to developing countries (see G/SPS/GEN/181; G/SPS/GEN/143; G/SPS/GEN/143/Rev.1/Add.1; G/SPS/GEN/78; G/SPS/GEN/124; G/SPS/GEN/244). What remains a concern is the inadequacy of the technical assistance given thus far to overcome the barriers to developing country products created by stringent SPS standards (see G/SPS/GEN/85 at 4).

32. The Decision on Implementation adopted at the Doha Ministerial Declaration on the basis of these discussions refers to implementation concerns regarding S\&D treatment and mandates the Committee on Trade and Development to examine the possibility of making non-mandatory S\&D provisions binding as well as other ways of improving the effectiveness of these provisions, and to report to the General Council with recommendations in this regard by July 2002 (see the Implementation Decision at para. 12). This work programme is endorsed in the Ministerial Declaration (see the Ministerial Declaration at para. 44).

33. See, for example, WT/GC/W/108 at para. 16.

34. In an earlier response of the LDC Coordinator to the Draft Ministerial Declaration, it is pointed out that it is not sufficient to provide technical assistance to help developing countries understand WTO rules and implement their obligations. Instead, technical assistance must go further and address supply side constraints (see the Statement of the Coordinator of LDCs on the Draft Ministerial Declaration, 2 October 2001 at 6). An example of such a constraint would be the inability to comply with SPS standards due to lack of technical capacity, expertise and infrastructure. The informal paper on implementation of a group of seven Members suggests that all $S \& D$ treatment provisions be converted into concrete commitments, 'especially to address the constraints on the supply side of developing countries' (see the Group of Seven Implementation Paper 2001 at 8-9).

35. See for example G/AG/NG/W/136 at 4 and G/AG/NG/W/37 at $6 \& 7$.

36. See for example G/AG/NG/W/142 at 3 and Group of Seven Implementation Paper 2001 at 3. It should be noted, however, that some or parts of the provisions which these proposals suggest be made mandatory (e.g. Article 10.1 and Annex B para. 2) are already mandatory, but difficult to enforce due to loopholes and flexible language.

37. See Group of Seven Implementation Paper 2001 at 3. 
and the creation of specific procedures ${ }^{38}$ to be followed to ensure that developing country constraints are taken into account. ${ }^{39}$

The Implementation Decision ${ }^{40}$ adopted in Doha addresses SPS-related concerns with regard to $S \& D$ treatment. The Decision is a compilation of proposals from developing countries, the 'Group of Seven' ${ }^{41}$ and the 'Quad' Members. In particular, the Decision stipulates time frames that were previously left open and sets some procedural rules for Articles 10 and 12.7.42

\section{Evaluation of developing country proposals and suggested amendments of the SPS Agreement}

The developing country proposals discussed above address significant problems faced by these countries regarding the effectiveness of the SPS Agreement in ensuring market access for their agricultural and food exports. Reforms are clearly needed to prevent evasion of the SPS disciplines by misuse of the flexibility inherent in the Agreement to impose unjustified measures. At the same time, it is necessary to ensure that developing countries receive the technical and financial assistance as well as special treatment they need in order to prevent legitimate SPS measures from constituting barriers to their export markets.

On the other hand, it is important to ensure that these two goals are met

38. See G/AG/NG/W/97 at $2 ; \mathrm{G} / \mathrm{AG} / \mathrm{NG} / \mathrm{W} / 100$ at 5 and WT/GC/W/108 at para. 16 .

39. A couple of interesting and very concrete proposals were made in this regard in the context of the Seattle preparatory process (see WT/GC/W/374 at para. 16 and WT/GC/W/108 at paras. $16 \& 18)$.

40. See the Implementation Decision WT/MIN(01)/W/10 at para. 3. This decision was drawn up and adopted separately from the Ministerial Declaration, which decision was criticised by some developing countries as potentially leading to the downplay of the importance of implementation issues (see the Statement of the Coordinator of LDCs on the Draft Ministerial Declaration, 2 October 2001 at 1 ).

41. See Group of Seven Implementation Paper, 2001.

42. According to the Implementation Decision, the 'longer time-frame for compliance' under Article 10.2 SPS must be understood to mean normally at least 6 months. Where no phased in introduction of a new SPS measure is possible and specific problems with the measure are identified by a Member, the Member imposing the measure must enter into consultations to find a mutually satisfactory solution while continuing to achieve the Member's appropriate level of protection. Further, it provides that the 'reasonable interval' under Annex B para. 2 must be understood to mean normally at least 6 months, taking into account that the timeframes for specific measures must be considered in the context of the particular circumstances of the measure and actions necessary to implement the measure. Further, that the entry into force of SPS measures that contribute to trade liberalisation should not be unnecessarily delayed. The Decision also proposes that review of the Agreement under Article 12.7 take place at least once every 4 years and that the Director-General continue his cooperative efforts with international standardsetting organisations to facilitate participation of Members at different levels of development (see the Implementation Decision, WT/MIN(01)/W/10 at para. 3). 
without disturbing the delicate balance aimed at by the SPS Agreement between the objective of ensuring market access for food and agricultural products and the sovereign right of governments to protect the life and health of humans, plants and animals in their territories. It goes without saying that both developed and developing countries have an interest in being able to act to address health risks in their territories, in a manner that reflects their national health priorities.

It seems that any workable solution to achieve an appropriate balance between the two aims of the SPS Agreement would involve guidelines further specifying the flexible provisions, which are largely concentrated in Article 5.7 and Article 3.3 SPS, coupled with a framework for effective technical and financial assistance and stricter rules on special treatment. Some tentative suggestions will be made along these lines, as a basis for further discussion.

Firstly, the loophole created in the scientific disciplines by Article 5.7 should be clarified. It is clear that scope for the application of provisional measures is necessary to deal with the realities of scientific uncertainty in risk regulation. This is not a new phenomenon and it is common practice for countries to act quickly in the face of a threat to health, without waiting for the results of risk analyses. However, this should not be allowed to become a catch-all provision for all measures lacking a scientific basis. It is therefore important that binding guidelines be drawn up that further define the conditions under which precautionary measures may be taken. In addition, the use of Article 5.7 should be limited to safety concerns and should not cover the ethical concerns of the consumers. Often these concerns are interrelated. Since ethical concerns can be considered legitimate, more attention should be paid to the clarification of other provisions under the WTO Agreements (mainly GATT Article XX, the TBT Agreement or under the negotiation process of Article 20 AoA) that could cover trade measures aiming to respond to these concerns.

It is suggested that the proposed guidelines make clear that the application of Article 5.7 is only triggered where 'scientific evidence is insufficient' due to the urgency of the measure, which made waiting for the results of a risk analysis unfeasible or due to gaps in existing scientific knowledge (for example regarding the long-term effects of GMO release into the environment). This would not be the case where scientific evidence exists, but does not support the measure. ${ }^{43}$ The 'reasonable period of time' before such a measure must be reviewed should be specified ${ }^{44}$ (for example at 6 months) with the provision that a Member maintaining the measure for a longer period without having obtained additional evidence to support a proper risk assess-

43. For example as was the case with the EC's ban on hormone-treated beef in the face of risk analyses showing the hormones to be safe if administered according to good veterinary practice (at issue in EC-Hormones WT/DS26/AB/R).

44. See the report of the Appellate Body in Japan-Agricultural Products, WT/DS76/AB/R at para. 93. 
ment bears the burden of proving why such additional time is necessary and why a risk assessment could not be performed in this period. These amendments would tighten the provisions of Article 5.7 and ensure that they are only used for legitimate purposes. While tightening the provisions, attention should be paid to preventing developing countries from becoming victims of these restrictions in future. The lack of scientific, technical and financial resources make it difficult, if not impossible, for them to apply the precautionary principle themselves. Defining a time limit that is too restricted, while allowing no budgetary or political justifications for longer periods, might eventually do more harm than good to developing countries. ${ }^{45}$

Secondly, it would be useful to tighten the flexibility resulting from the wording of Article 3.3. Tightening it as far as obliging all Members to adopt international standards is to be rejected, as these standards represent a compromise agreement on a minimum level of protection and such an obligation would be contrary to the acknowledged sovereign right of governments to decide on the appropriate level of protection to be applied in their territories. In addition, the paralysis of the standard-setting procedure that would result in the postponement of the adoption of standard, or even no adoption at all, would have negative consequences for developing countries in particular. As developing countries often do not have standards in place, international standards provide them with a certain degree of protection. They also set a benchmark against which other countries' standards can be challenged.

However, a reformulation of this provision to indicate that deviation must always be based on a risk assessment would be useful to avoid the confusing impression created by its wording that there are two possibilities for the justification of deviating measures. ${ }^{46}$ Further, the provision could be amended to oblige developed country Members that impose stricter measures than those reflected in international standards to promptly notify their intention to impose such measures ${ }^{47}$ respond to all comments received regarding the measure and, to the extent that the measure has a negative impact on exports from developing countries, provide technical and financial assistance to enable

45. It is interesting to note that in the framework of the Biosafety Protocol, the majority of developing countries and the European Union were in favour of the inclusion of the precautionary principle. In their opinion, however, the precautionary principle needed to be backedup by the adoption of a liability regime. Some developing countries expressed that such a regime could give a certain guarantee which is in their opinion necessary as the WTO rules restrict in particular the countries with limited scientific and technical expertise to justify their import restrictions based on the precautionary principle (Summary of the Fifth Meeting of the Openended ad hoc Working Group on Biosafety: 17-28 August 1998, Earth Negotiations Bulletin, IISD, Vol. 9, no. 108, 31 August 1998, p. 12).

46. The Appellate Body stated in EC-Hormones that 'Article 3.3 is evidently not a model of clarity in drafting' (see WT/DS26/AB/R at para. 173).

47. See the arguments of India (WT/GC/W/108 at para. 18). 
these countries' producers to meet the new standard. ${ }^{48}$ In this way, technical and financial assistance will be directly linked to the measures encompassing a higher level of protection and the need of developing countries resulting therefrom. Such an obligation will ensure that Members do not lightly deviate from an international standard and, in cases where they are convinced that such deviation is necessary, that they take responsibility for the effects of the deviation on developing country exports.

Even though it does not go as far as obliging all Members to adopt international standards, the suggested amendment would, of course, increase once again the importance of the standards set on international level. With this shift, the concerns related to the democratic and effective functioning of standard-setting bodies become more important and need to be evaluated. At present, despite initiatives of the standard-setting organisations in this regard, developing country participation in the international standard-setting process leaves much to be desired. They do not have the resources to attend the plethora of committees (often hosted by developed countries) that prepare the standards and they thus often limit their participation to the plenary session where the proposed standards are adopted. Although developing country participation in plenary sessions is increasingly active, at this late stage, the concerns they raise cannot be adequately addressed nor compromises reached and the resulting absence of consensus prevents the adoption of any standard. Clearly this result is contrary to the interests of developing countries in extending the harmonisation for standards as much as possible. The last meeting of the Codex Alimentarius Commission ${ }^{49}$ clearly illustrated this problem. The possibility that this untenable situation may lead to a movement away from consensus decision-making in standard-setting organisations is also worrying as the standards adopted would lose their legitimacy as internationally accepted norms. It is thus of the utmost importance to ensure effective participation of developing countries in all stages of the standard-setting process.

The provision in Article 9 SPS stating that Members 'should' encourage and facilitate the active participation of developing countries in these organisations has not been effective. What is needed are not meetings with developing countries during which they are encouraged to support the position of the developed country involved, but rather effective technical and financial assistance to developing countries to enable them to identify and promote

48. This follows the proposal by the group of eight developing countries during the Seattle preparatory process mentioned above, but limits its application to SPS measures that deviate from international standards (see WT/GC/W/374 at para. 16). It also corresponds to the suggestion by the Coordinator for LDCs in the response written on the Draft Ministerial Declaration, for the inclusion of an agreement to provide technical and financial support to LDCs before the introduction of new SPS measures which adversely affect LDC exports (see Statement of the Coordinator of LDCs on the Draft Ministerial Declaration 2001 at 8).

49. The 24th Session of the Codex Alimentarius Commission was held in Geneva on 2-7 July 2001. 
their own interests. To ensure that no strings are attached to such assistance and that it is supplied in a secure and predictable manner, it would be best if it were administered by the WTO itself on the basis of funding from the regular (but increased) WTO budget, which is contributed to by all Members according to their share in world trade. ${ }^{50}$ In this way, financial support could be given for developing country delegates to attend all meetings, ${ }^{51}$ for training programs for such delegates and for coordination with their national ministries. $^{52}$

Additionally, while the WTO cannot prescribe to other international organisations how they should conduct their activities, it may decide for itself which of the standards adopted by such organisations it will regard as relevant for its purposes. In this context, the definition of 'international standards, recommendations and guidelines' in Annex A SPS needs to be looked at closely, in order to differentiate between the various types of instruments used by international standard-setting organisations, and reconsider whether they should have the same status under the SPS Agreement. For instance, at this moment food safety standards developed by the Codex Alimentarius would have the same status as its general principles once they are adopted,$^{53}$ whereas the function of the instruments is quite different.

Lastly, it is necessary to address the issue of time frames for imposition of and compliance with new or stricter SPS measures. As stated above, fixed time frames under Article 10.2 and Annex B paragraph 2 would lead to the untenable situation that Members could not prevent the inflow of even dangerous products and proposals to set fixed time frames should therefore be

50. It would seem logical for this fund to be set up and administered by the international standardsetting organisation itself. However, the WTO has no say over the activities of these organisations and cannot oblige them to take such a step. Nor do their members have any obligation to contribute to a fund on the basis of a WTO decision. The added relevance of the standards set by these organisations is due to the reliance thereon by the SPS Agreement and the problems caused thereby are therefore an issue that the WTO should deal with. It is, however, possible that an agreement could be reached between the WTO and each standard-setting organisation in which the standard-setting organisation agrees to take over these duties.

51. This is already done by the OIE, which has a fund from which developing country delegates' costs for attending the plenary sessions are met.

52. The need for technical assistance to be secure and predictable was recognised in the Doha Ministerial Declaration and the Budget Committee was instructed to develop a plan ensuring long term funding for WTO technical assistance for adoption by the General Council in December 2001 (see Ministerial Declaration WT/MIN(01)/DEC/W/1at para. 40). In its first meeting on this issue the Committee considered a proposal by the Director-General to create a Doha Development Agenda Global Trust Fund, financed by voluntary contributions coupled with a monitoring mechanism to ensure timely and predictable funding. Some Members raised concerns regarding the voluntary nature of the funding, arguing for financing from the WTO's regular budget (see Bridges, 40(5), 28 November 2001 at 4).

53. The SPS Committee responded to the question from the Codex Alimentarius Commission on the status of Codex texts by saying that the SPS Agreement did not establish any distinction between different types of Codex texts directed to governments, ALINORM 99/33, paras. 50-52. 
rejected. The Implementation Decision contains a more flexible specification of the time frame for phased introduction of a measure under Article 10.2 SPS as 'normally a period of not less than 6 months', coupled only with a consultation obligation 'with a view to finding a mutually acceptable solution' that maintains the importing Members appropriate level of protection, where phased introduction is not feasible. ${ }^{54}$ This may lead to a continuation of the situation as it now stands, where no effort is being made to identify situations where such delayed compliance would be feasible. It is thus proposed that the recommended period for compliance by developing countries (which could be left at 6 months) be coupled with a shift of the burden of proof to the Member applying the new measure without allowing for delayed compliance to indicate reasons why this additional period could not be allowed. In this way, the starting point would be the granting of a longer compliance period to developing countries which could not be avoided by mere consultations, but the additional period would not be required where an unacceptable health risk would result. An analogous solution could be applied to the time frame for the coming into force of new measures under Annex B paragraph 2 to replace the 'normally a period of not less than 6 months' interpretation laid down in the Implementation Decision. ${ }^{55}$

\section{Conclusion}

It is not the purpose of this article to cover all aspects of the SPS Agreement that need to be addressed in order to accommodate developing country concerns, but merely to make a few suggestions that could form a starting point for further discussion and more concrete proposals for reform. It is hoped that by contributing to the discussion on possibilities for reform of the SPS Agreement, further steps can be taken towards reaching a solution that both addresses the legitimate concern of developing countries to ensure that the SPS Agreement's disciplines result in tangible benefits in terms of market access for their agricultural and food products, and the equally important goal of ensuring that Members' ability to protect health within their territories is not compromised. It is clear that reforming the SPS Agreement cannot stand by itself, but comes with amending in conjunction the relevant provisions of other WTO Agreements and the functioning of the relevant international standard-setting bodies.

54. Implementation Decision $\mathrm{WT} / \mathrm{MIN}(01) / \mathrm{W} / 10$ at para. 3.1.

55. Implementation Decision WT/MIN $(01) / \mathrm{W} / 10$ at para. 3.2. Here the 6 -month time frame is qualified by a requirement that the circumstances of the measure and the actions necessary for its implementation be taken into account. These considerations, as well as the further provision that trade liberalising SPS measures should not be unnecessarily delayed, should be maintained. 


\section{Bibliography}

Group of Seven. 2001, Group of Seven Implementation Paper: Proposals on Implementation, informal paper presented in the implementation consultations in the WTO General Council, available at: www.ictsd.org/ministerial/doha/implementation.pdf

FAO. 1999, Symposium on Agriculture, Trade and Food Security: Issues and Options in the Forthcoming WTO Negotiations From the Perspective of Developing Countries, 23-24 September 1999, Food and Agriculture Organization: Geneva

McNiel, D.E. 1998, 'The first case under the WTO's Sanitary and Phytosanitary Agreement: the European Union's hormone ban.' Virginia Journal of International Law 39

Statement of the Coordinator of LDCs on the Draft Ministerial Declaration, 2 October 2001, available at: www.wtowatch.org/library/admin/uploadedfiles/Statement_of_the_coordinator_of_the_ LDCs_on_th.htm

Trade and Development Board, UNCTAD. 1999, Examining trade in the agricultural sector, with a view to expanding the agricultural exports of the developing countries, and to assisting them in better understanding the issues at stake in the upcoming agricultural negotiations TD/B/COM.1/EM.8/2, 23 February, United Nations Conference on Trade and Development: Geneva

WTO Appellate Body Report. European Communities - Measures Concerning Meat and Meat Products (Hormones), WT/DS26/B/R, 16 January 1998

WTO Appellate Body Report. Japan - Measures Affecting Agricultural Products WT/DS76/AB/R, 22 February 1999

WTO Committee on Agriculture. 2000, Market Access: Submission by Cuba, Dominican Republic, El Salvador, Honduras, Kenya, India, Nigeria, Pakistan, Sri Lanka, Uganda, Zimbabwe G/AG/NG/W/37, 28 September, World Trade Organization: Geneva

WTO Committee on Agriculture. 2000, Proposal for Comprehensive Long-Term Agricultural Trade Reform: Submission by the United States G/AG/NG/W/15, 23 June, World Trade Organization: Geneva

WTO Committee on Agriculture. 2000, WTO Negotiations on Agriculture: Proposal by the EC G/AG/NG/W/19, 28 June 2000

WTO Committee on Agriculture. 2000, WTO Negotiations on Agriculture: Proposals by Small Island Developing States (SIDS): Communication from Barbados, Cuba, Dominica, Jamaica, Mauritius, St. Kitts and Nevis, St. Lucia, St. Vincent and the Grenadines, and Trinidad and Tobago G/AG/NG/W/97 and Corr. 1, 29 December, World Trade Organization: Geneva

WTO Committee on Agriculture. 2000, WTO: Negotiations on Agriculture: Proposal by Switzerland G/AG/NG/W/94, 21 December, World Trade Organization: Geneva

WTO Committee on Agriculture. 2000, WTO: Negotiations on Agriculture: Proposal by the EC G/AG/NG/W/90, 14 December 2000

WTO Committee on Agriculture. 2001, Proposal for WTO Negotiations on Agriculture: Submitted by the Republic of Korea G/AG/NG/W/98, 9 January, World Trade Organization: Geneva

WTO Committee on Agriculture. 2001, WTO Negotiations on Agriculture - Market Access: Negotiating Proposal on Behalf of the Members of the Caribbean Community (Caricom) G/AG/NG/W/100, 15 January, World Trade Organization: Geneva

WTO Committee on Agriculture. WTO negotiations on agriculture: Proposal by Nigeria G/AG/NG/W/130, 14 February, World Trade Organization: Geneva

WTO Committee on Agriculture. 2001, WTO African Group: Joint Proposal on the Negotiations on Agriculture G/AG/NG/W/142, 23 March, World Trade Organization: Geneva

WTO Committee on Agriculture. 2001, WTO Negotiations on Agriculture: Proposal by Kenya G/AG/NG/W/136, 12 March, World Trade Organization: Geneva

WTO Committee on Agriculture. 2001, WTO Negotiations on Agriculture: Proposal by Namibia in the areas of: (i) Market access, (ii) Domestic support, (iii) Export competition, and (iv) Non-trade concerns G/AG/NG/W/143, 23 March, World Trade Organization: Geneva

WTO Committee on Sanitary and Phytosanitary Measures. 1998, Special and differential treatment 
and technical assistance: Submission made by India at the meeting of 10-11 June 1998 G/SPS/GEN/85, 23 July, World Trade Organization: Geneva

WTO Committee on Sanitary and Phytosanitary Measures. 1998, Technical cooperation and assistance: Submission by the United States G/SPS/GEN/78, 9 June, World Trade Organization: Geneva

WTO Committee on Sanitary and Phytosanitary Measures. 1999, Quarantine and other sanitary and phytosanitary capacity building and training activities undertaken by Australia: Submission by Australia G/SPS/GEN/124, 15 June 1999, World Trade Organization: Geneva

WTO Committee on Sanitary and Phytosanitary Measures. 1999, SPS Agreement and developing countries: Statement by Egypt at the meeting of 7-8 July 1999 G/SPS/GEN/128, 16 July 1999, World Trade Organization: Geneva

WTO Committee on Sanitary and Phytosanitary Measures. 1999, Summary of the replies to the questionnaire on technical assistance: Note by the Secretariat G/SPS/GEN/143, 8 November, World Trade Organization: Geneva

WTO Committee on Sanitary and Phytosanitary Measures. 2000, Summary of the replies to the questionnaire on technical assistance: Note by the Secretariat. Addendum G/SPS/GEN/143/Rev.1/Add.1, 16 June, World Trade Organization: Geneva

WTO Committee on Sanitary and Phytosanitary Measures. 2000, Technical assistance to developing countries provided by the United States: Submission by the United States G/SPS/GEN/181, 15 June, World Trade Organization: Geneva

WTO Committee on Sanitary and Phytosanitary Measures. 2000, Communication from the Commission on the Precautionary Principle, G/SPS/GEN/168, World Trade Organization

WTO Committee on Sanitary and Phytosanitary Measures. 2001, European Council Resolution on the Precautionary Principle, G/SPS/GEN/225, World Trade Organization: Geneva.

WTO Committee on Sanitary and Phytosanitary Measures. 2001 Decision on Equivalence, G/SPS/19, 24 October, World Trade Organization: Geneva

WTO Committee on Sanitary and Phytosanitary Measures. 2001, Technical assistance to developing countries: Statement by the European Communities at the meeting of 14-15 March 2001 G/SPS/GEN/244, 27 April, World Trade Organization: Geneva

WTO General Council. 1998, Concerns regarding implementation of provisions relating to differential and more favourable treatment of developing and least-developed countries in various WTO Agreements: Communication from India WT/GC/W/108, 13 November, World Trade Organization: Geneva

WTO General Council. 1999, Communication from Cuba, Dominican Republic, Egypt, El Salvador, Honduras, Sri Lanka, Uganda and Zimbabwe WT/GC/W/374, 15 October, World Trade Organization: Geneva

WTO Information and Media Relations Division 2001, WTO agriculture negotiations: The issues, and where we are now. 2 October, World Trade Organization: Geneva, available at: www.wto.org/english/tratop_e/agric_e/agnegs_bkgrnd_e.pdf

WTO Ministerial Conference, Fourth Session. 2001, Implementation-Related Issues and Concerns: Decision WT/MIN(01)/W/10, 14 November, World Trade Organization: Doha

WTO Ministerial Conference, Fourth Session. 2001, Ministerial Declaration WT/MIN(01)/DEC/W/1, 14 November, World Trade Organization: Doha 